\title{
Enhancing Youth Employability as a Result of Creating Linkages between Vocational Education Sector and Private Agricultural Sector in Kosovo
}

\author{
$\mathrm{PhD}$ (c) Emine Daci-Zejnullahi
}

\author{
AAB University, Prishtinë, Kosovë \\ eminedaci@hotmail.com \\ Petrit Bushi \\ AAB University, Prishtinë, Kosovë \\ petrit.bushi@universitetiaab.com
}

Doi:10.5901/ajis.2015.v4n1s2p61

\begin{abstract}
The agribusiness and Agriculture sector is the main field of economy in Kosovo and it is sector that contributes to social viability, employment and economic development. While in Kosovo on the basis of statistics from the results of the Kosovo labor force survey 2014, shows that Kosovo stands in the worst labor market situation in comparison to the Western Balkan countries and the 27 European Union member countries. The unemployment rate in Kosovo is 30\%, from these percentage $55.9 \%$ of the unemployed were young people (aged 15-24 years) and the share of female population is higher $68.4 \%$. The labor force participation rate in Kosovo is $40.5 \%$ while the participation rate in Western Balkan countries ranges between 60 to $68 \%$ and it is $71.8 \%$ in European Union countries. Part of these differences is due to the fact that Kosovo has such a young population and many of these young people are still in education (and therefore classified as inactive). A concern is that over time the potential for the inactive population to grow remains high as each year approximately 36,000 young people will enter the working age population (i.e., 14 year olds will become 15 year olds) while only approximately 10,000 will leave the working age population (i.e., 64 year olds becoming 65 year olds). Very strikingly, the labor force participation rate of women is significantly lower in Kosovo than its neighbors1. This study intends to serve as a key tool for identifying the gaps between vocational education sector and private agricultural sector in Kosovo, which impact directly to the unemployment rate. The research addressed identified gaps of the VET schools and Private sector, their needs, areas of focus, specific needed activities in order to create the favorable conditions to link these two important sectors and enhance youth employability.
\end{abstract}

Keywords: VET schools, agribusiness sector, youth employment,

\section{Introduction}

In order to have better understanding of gaps and needs of Agribusiness sector and VET schools, we conducted the assessment with private sector companies and three main VET schools in Kosovo. Considering the agriculture and agribusiness fields as main potentials of rapid youth employment, the Kosovo government with the support and cooperation different donor agencies and organization experienced and active in this sector aims to enhance and support this potential among youth of 17-20 ages who graduate in vocational secondary agriculture schools, enhancing of the youth employability should work on improving theoretical, practical needed skills and linking with private sector. Through these efforts they should up upgrade the level of qualitative professional skills among youth in order to enhance their opportunities for employment during attending or after completion of secondary vocational education. On the other side it seems to be a low interest of Kosovo society, particularly of youth to work in agriculture, even though this society has a long tradition working in agriculture and Kosovo has an appropriate terrain / land and climate of growing agriculture products. So far, in Kosovo we miss tracer information about youth who have already completed the secondary vocational education in agriculture. Where and how they may have continued their further career, through continuation of University studies or through employment / self-employment in the agribusiness industry (or others), even the second issue is not as sustainable as the unemployment level among youth in Kosovo is very high. Unemployment and its impact

${ }^{1}$ Kosovo Agency of Statistics 
on young people are serious issues that affect the development and wellbeing of Kosovo youth. In a region where there is high youth unemployment, young people must be recognized as a resource for progressive economic development; therefore, the Government should create mechanisms to ensure that young people are involved in the economic development strategies, and that youth issues are considered as a priority ${ }^{2}$

\section{Objectives of this Research}

The objectives of this assessment are to:

- Develop a clear understanding of needs and the state of targeted VET schools and private agribusiness sector;

- Identify gaps and opportunities that can be addressed by Kosovo institutions and different donors active in this sector

- Develop specific approach and intervention methodologies and activities

\section{Materials and Methods}

The Questionnaire was conducted throughout Kosovo; first we developed selection criteria/methodology through including main subsectors, three levels of businesses and all value chain actors. Whereas businesses that were interviewed were selected based on these criteria:

- Small, medium and large agribusinesses

- Agribusinesses with potential growth for enhancing youth employability.

- Agribusinesses which were based in the same region as Agricultural VET Schools.

- Businesses that are registered (legal)

- Businesses they have products in the regional and international market

Interviews were carried out face - face with high level of management: owners, directors, coordinators etc. In terms of business activity all value chain actors were involved such us: producers, processors, traders, service providers etc. The sample was classified into municipalities' and regional level, based on the presence of the representative agribusinesses; the sample was different from one to other municipalities and from one to another region and level of businesses. The assessment was based on quantitative analysis and qualitative analysis. The 100 questionnaires were conducted with the agribusiness companies, 234 with VET students from the three schools and qualitative data with three school directors of VET schools from Pristina, Peja and Ferizaji.

\section{Results of Research}

\subsection{Results obtained on the ground}

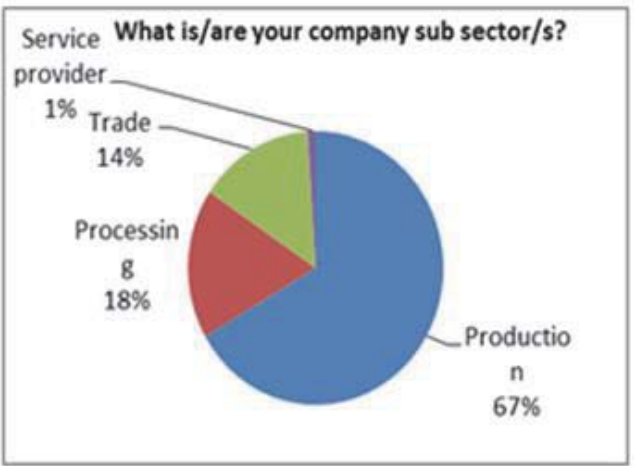

Figure 1: \% Assessment of business subsectors: producers, processors, traders, service providers,

2 Kosovo Youth Strategy and Action Plan 2010-2012, page 12. 
The majority of the respondents, about $67.0 \%$ answered that they belong to the producers sector, while $18 \%$ of respondents were from the processing sector, $14 \%$ of respondents were from agribusiness traders companies that deal with export-import, around $1 \%$ service providers. It means that the survey was conducted with biggest producers, and big processors, having higher development potential.

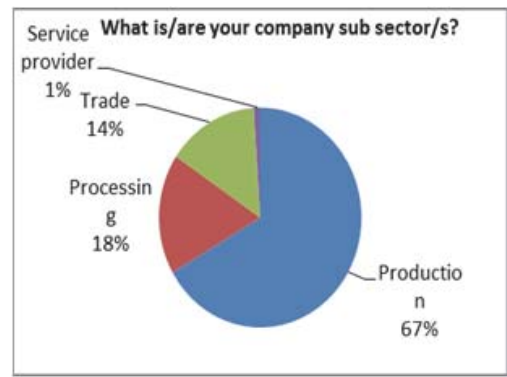

Figure 1: \% of company subsectors

Regarding the question "What is the average age of the employees", majority of them $72.6 \%$ of interviewed companies stated that average age is 25-34 years old, while $20 \%$ stated that average age is $35-44 \%, 4.2 \%$ of interviewed companies has workers in the average age 15- 24 and $3.2 \%$ of respondents stated that have workers in their companies in average age more than 45 year
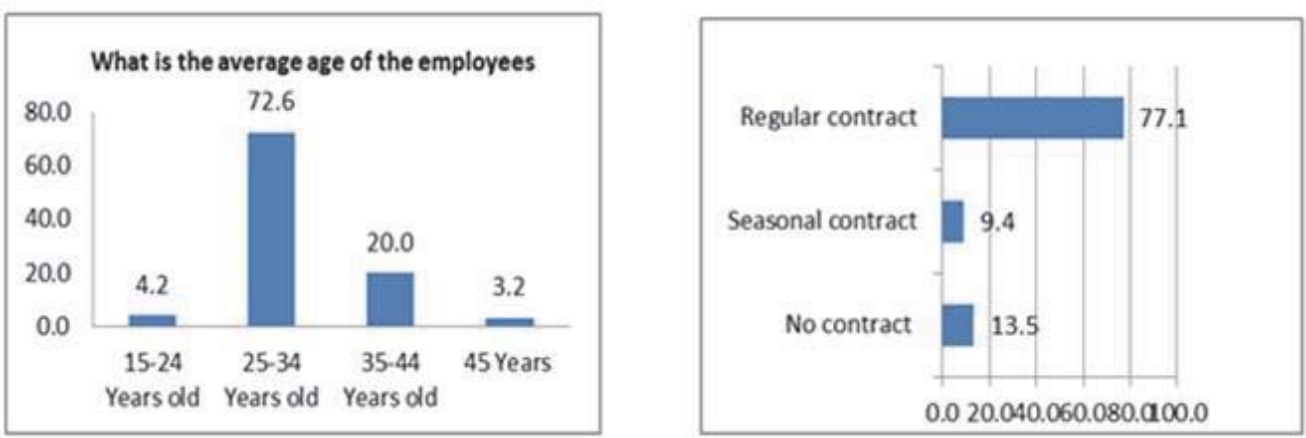

Figure 2: \% of different types of employee contract

Figure 3: what types of work contract have the Employees

Regarding the figure 3 it is mean that $77.1 \%$ of employees have the regular contract, $13.5 \%$ of employees without working contract and $9.4 \%$ of employees have the seasonal contract.

According the question" How do you announce vacancies for your employees, especially when they have freshly graduated from school? From the total number of companies $25.6 \%$ stated that they employ fresh graduate through family connections, while $20.9 \%$ through the Employment office, $16.3 \%$ advertisement in newspaper and $11 \%$ of stated they announce
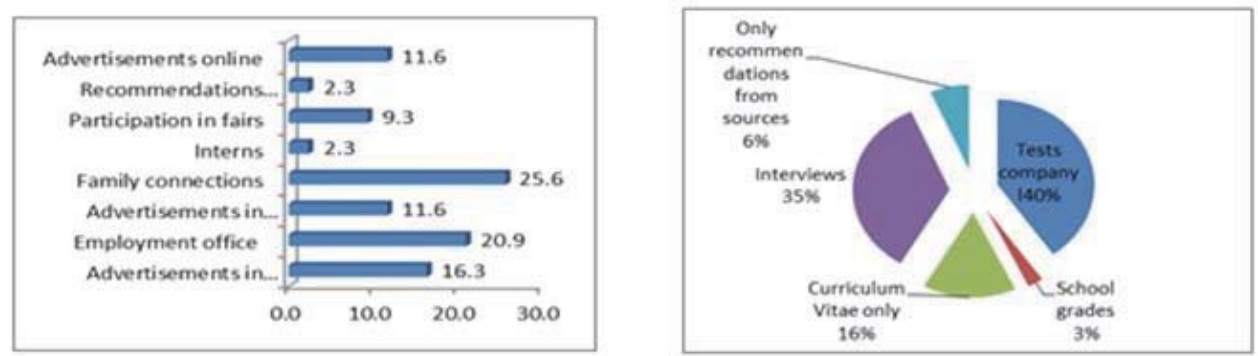

Figure 4: $\%$ of different announcement of vacancies

Figure 5: \% of company's opinion regarding use of different instruments for hiring of fresh graduates 
Regarding the question about the means that companies use for hiring the fresh graduates $40 \%$ of companies stated that they use test at their company, 35\% using interviews and 16\% looking to the Curriculum vitae and very low \% about 6\% consider the recommendations. It is meaning that most appropriate tool for youth employment is tests at their company and interviews. Regarding the figure 6 the most of companies around $78.7 \%$ stated that they satisfied with the youth work (fresh graduates) and $21.3 \%$ give the negative opinion regarding satisfaction with youth work.
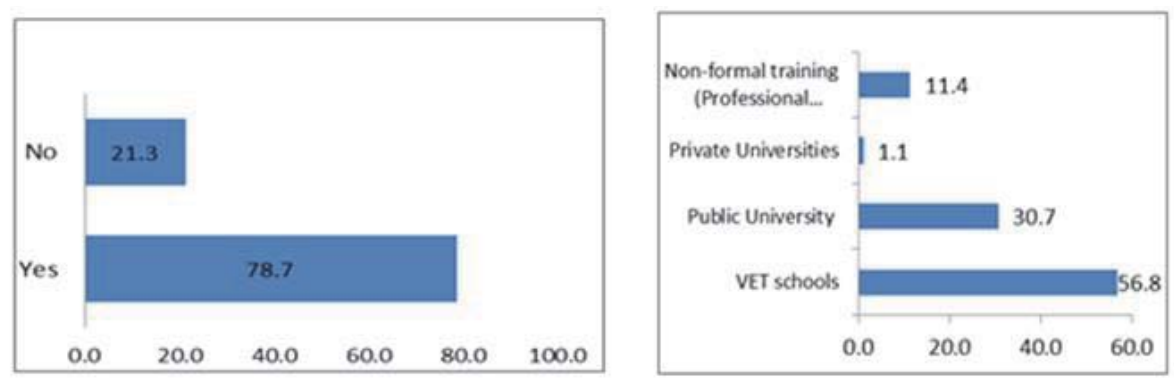

Figure 6: \% of satisfaction with youth work

Figure 7: \% preferences of companies for Institutions where youth Employees come from?

It is interesting that the private sector around $56.8 \%$ preferred young employees to come from VET schools, while 30.7 from public universities, 11.4 from professional certification institutions and very low \% from private universities around 1.1\%.So agribusiness companies are optimistic about students that came from Agribusiness VET schools. Findings indicate that about 79.2 percent of companies stated that they are interested to employ young people from VET Schools while 20.8 percent they aren't interesting. In conclusion the agribusiness companies seem to be very interesting in employing the youth from VET schools.
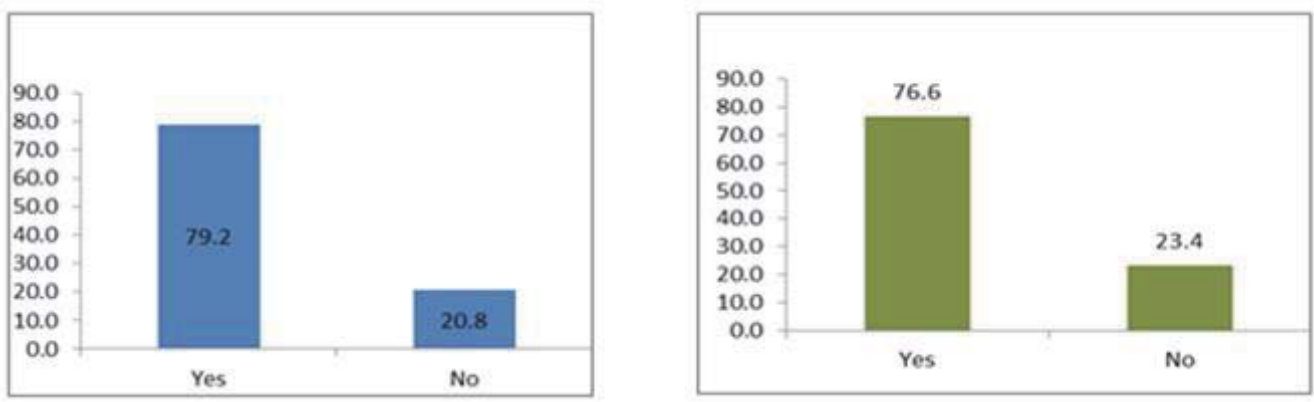

Figure 8: Are you interested to employ young

Figure 9: Did you ever have internships in your company?

\subsection{People from VET Schools}

According to the figure in left side 79.2 percent companies are interest in employing the youth form VET schools. Results presented in Figure 9 reveal that for almost 76.6 percent had the internships while 23.4 percent didn't had internships before. Since in the figure bellow is presented the joint activity between Companies and VET schools, most of the joint activities were the exchange visits 73 percent, participation in job fairs 20 percent while other activities as open school days and participation of student in joint promotion of companies' products are in very low level.

Table 1 outlines the \% of companies interest in particular profile. It seems the interviewed companies are more interesting for wood technology (100\%), Horticulture profile (62.0\%), food technology (57.8\%), plant protection (10.8\%), crop and vegetable production (10.8\%) while the other profile are less required from the agribusiness companies. It is mean that we have to target the students from these profiles and link with the companies in order to address their needs and contribute to youth employability and employment. 
Table 1: \% of inters of companies for Agribusiness profiles according to sectors and subsectors

\begin{tabular}{cccc}
\hline Nr. & VET Agribusiness profile & Yes (\%) & No (\%) \\
\hline 1 & Farmer profile & 9.5 & 85.5 \\
2 & Horticulture & 62.0 & 38.0 \\
3 & Crop and vegetable growing & 10.8 & 89.2 \\
4 & Food technology & 57.8 & 42.2 \\
5 & Veterinary & 2.4 & 97.6 \\
6 & Forestry & 4.0 & 96.0 \\
7 & Livestock & 3.6 & 96.4 \\
8 & Plant protection & 10.8 & 89.2 \\
9 & Tree -viticulture & 6.0 & 94.0 \\
10 & Wood technology & 100 & 0 \\
\hline
\end{tabular}

Table 2 outlines the \% of importance of different working skills of VET students for agribusiness companies. It seems the very important skills for interviewed companies are these skills: skill to do "Quality of work, attention to details" (90.8 \%), Team working (84.5\%, Knowledge for using equipment (75.6 \%), experience in similar positions (61.2 $\%)$,Communication Skills (59.8 \%),interpersonal skills(53.7\%) and important skills are Formal education(64.3\%), Foreign language skills (57\%), Training and certification (54.8\%).

Table 2: \% of importance of different working skills of VET students for agribusiness companies

\begin{tabular}{|c|l|c|c|c|}
\hline $\mathrm{Nr}$ & \multicolumn{1}{|c|}{ Not Important } & Important & Very important \\
\hline 1 & How important is the work experience in similar positions & 3.5 & 35.3 & 61.2 \\
\hline 2 & How important is Formal education & 8.3 & 64.3 & 27.4 \\
\hline 3 & How important is the Trainings and Certifications & 20.2 & 54.8 & 25.0 \\
\hline 4 & How important is the Knowledge using equipment & 3.7 & 19.5 & 75.6 \\
\hline 5 & How important is the Foreign language skills & 14.0 & 57.0 & 29.0 \\
\hline 6 & How important is the Communication Skills & 8.0 & 32.2 & 59.8 \\
\hline 7 & How important is the Interpersonal skills & 7.3 & 39.0 & 53.7 \\
\hline 8 & How important is the Quality of work, attention to details & 9.2 & 0.0 & 90.8 \\
\hline 9 & How important is the Team working & 15.5 & 0.0 & 84.5 \\
\hline
\end{tabular}

Regarding the question 10" Did you have any joint activity with the VET schools", $73 \%$ of companies interviewed stated that one of activities which was most frequented is exchange visits between two sectors, $20 \%$ job fairs, $5 \%$ of companies stated that they engaged student for promotion of their companies product, while very low percent $2 \%$ in open school days. It is meaning that one of most appropriated activities between these two sectors is exchange visits and job fairs.

Figure 10: \% of joint activities between companies and VET schools

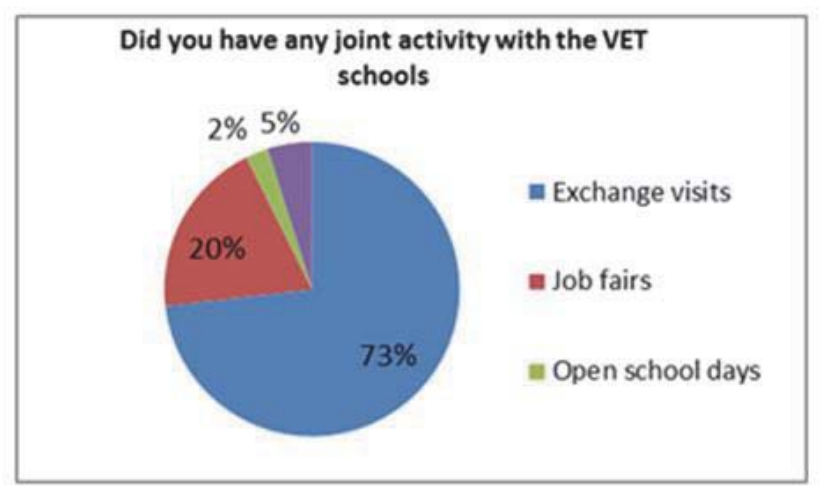

Regarding the question in the figure 11 "Are you willing to accept internships in your business in order to develop 
practical knowledge "most of companies 73.9 percent gave the positive answer while 26.1 percent stated no.

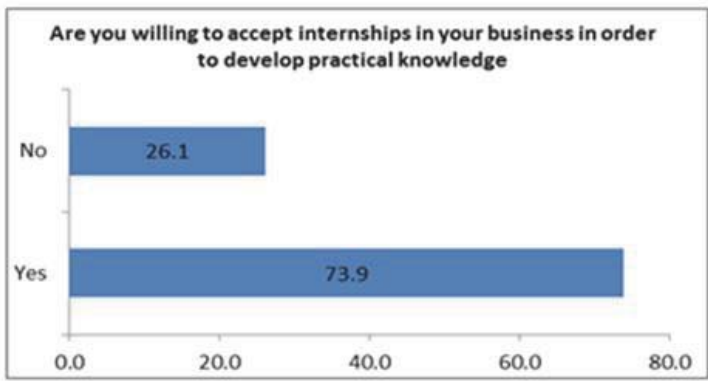

Figure 11: \% Companies willing to accept internships in their companies

The most of companies in the past supported the internships activity with providing to the students the additional contribution like: food, transport, half wage, and paid training course. In line with responses related to the different contributions of companies for internships most of the companies 67.1 percent stated that they provided food for students, 33.0 provided the half wage, 31.8 provide the transport and 21.2 percent of companies stated that they have paid training courses.

Table 3: \% Different contributions of companies' for internships

\begin{tabular}{|cc|c|c|}
\hline Nr. & Contributions of companies for internships & Yes (\%) & No (\%) \\
\hline 1 & Providing food & 67.1 & 32.9 \\
\hline 2 & Providing the transport & 31.8 & 68.2 \\
\hline 3 & Half wage & 33.0 & 67.0 \\
\hline 4 & Paid training course & 21.2 & 78.8 \\
\hline
\end{tabular}

In the Figure bellow regarding the question about "Do the companies plan to expand their businesses", most of them 93.7 percent declare yes and low percent 6.3 percent declare no.

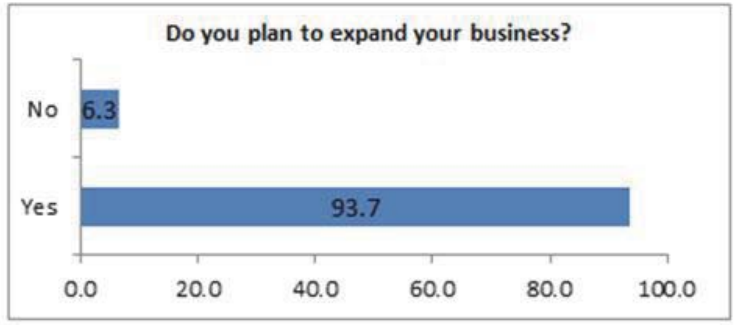

Figure 12: \% companies that plan to expand their businesses

In additional regarding the question about the plans of companies in future 93 present of companies plan to expand their businesses while $63 \%$ increase productivity, $50 \%$ increase number of employees and low number of companies stated 44.4 percent are interest to expand new product.

Table 4: Plans of companies in future

\begin{tabular}{clcc}
\hline Nr. & & Yes (\%) & No (\%) \\
\hline 1 & Do you plan to expand your business? & 93.7 & 6.3 \\
2 & Do you plan to increase number of employees & 50.0 & 50.0 \\
3 & Do you plan to expand your business increase productivity & 63.0 & 37.0 \\
4 & Do you plan to expand your business with the new product & 44.4 & 56.6 \\
\hline
\end{tabular}


With regard to question which is presented in the figure 13 we receive very interesting answer that 50 percent of companies declare that they plan to increase number of employees and 50 percent no. It is mean that we are satisfied with the businesses declarations regarding the potential readiness to increase number of employees

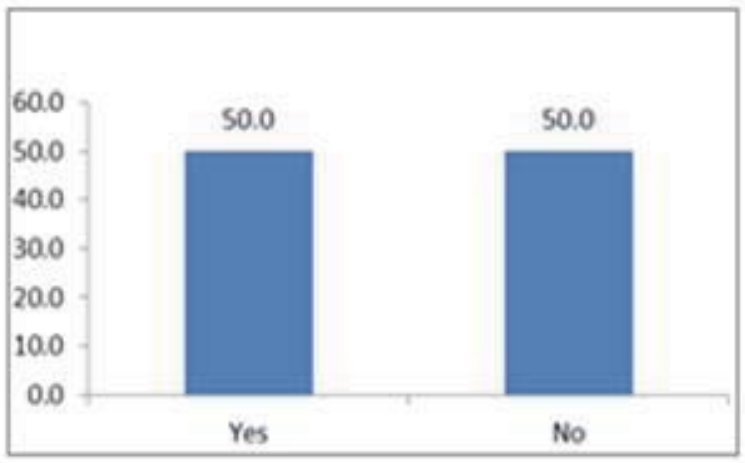

Figure 13: \% companies that they plan to increase the number of employees in near future

\subsection{Assessment of VET student of agribusiness schools}

The assessment was also conducted with the 234 VET students in three Agribusiness VET schools: Abdyl Frasheri in Prishtina, Zenel Hajdini in Ferizaj municipality and Ali Hadri in Peja municipality. 234 students were interviewed face to face in order to identify their gaps and opportunities regarding employability and employment. The interviews were distributed in the three schools based on number of VET student that schools possess and the profiles that businesses are interest. The $43.5 \%$ of student interviewed were from school "Zenel Hajdini", $36.0 \%$ from VET school "Avdyl Frasheri" and $20.5 \%$ from VET school "Ali Hadri".
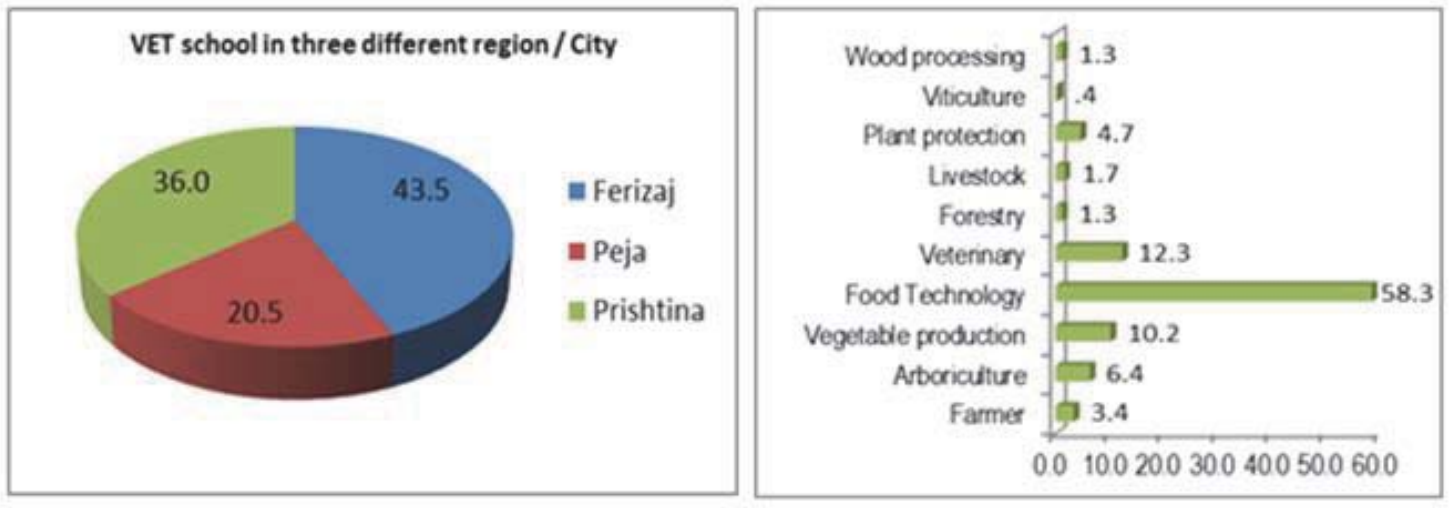

Figure 14: \% of students interviewed in the three Figure 15: \% of different profiles of students interviewed VET schools

The different profiles of student were interviewed during the assessment, the one of most frequented was the food processing profile which in this assessment presents $58.3 \%, 12.3 \%$ of veterinary profile, $10.2 \%$ vegetable production profiles, $6.4 \%$ Arboriculture profile. The request of KCC to conduct the interviews with the profiles which were most requested from the private sector.

According to the question for VET schools which is showed in the figure 17 below $50.2 \%$ of students belong to the $12^{\text {th }}$ classes and $49.8 \%$ belong to the $13^{\text {th }}$ classes, which mean that almost 50:50 of different classes represented their opinion about skills, gaps and needs. 

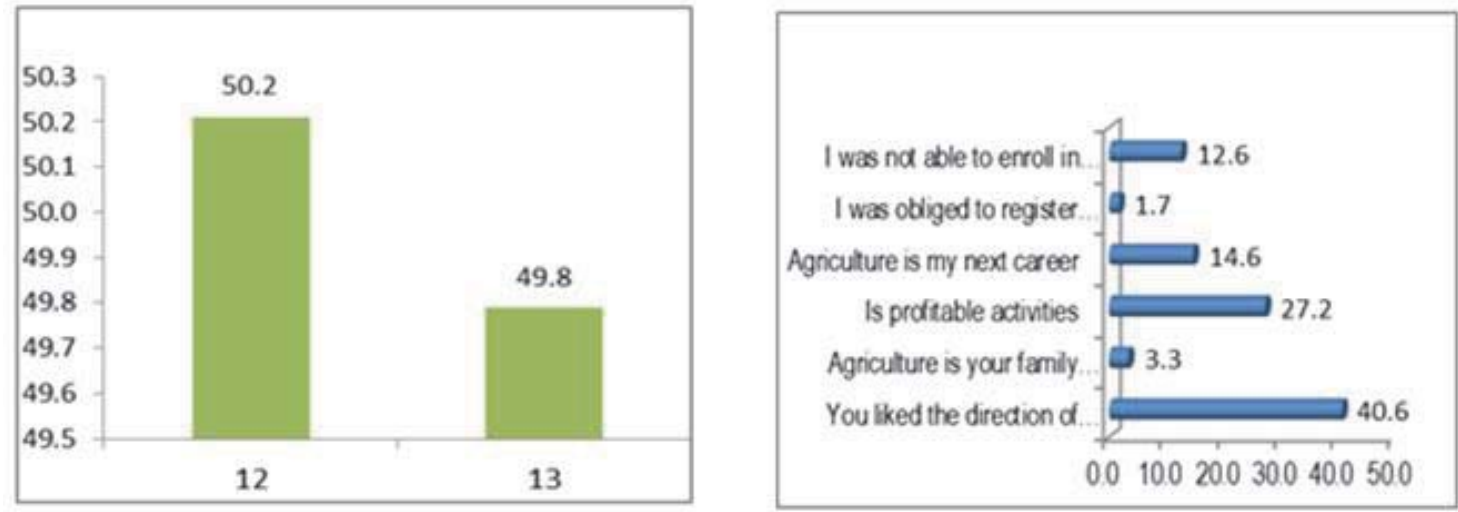

Figure 16: \% of different classes that were interviewed Figure 17: How they decided to enroll the Agriculture VET school

According to the figure 18 above we see that even it was thought that majority of students were enforced from family or they were not able to enroll in other schools, based on the percent presented above most of them liked this field and it was their decision $40.6 \%$, they see that this field is profitable $27.2 \%$, agriculture is their carrier $14.6 \%$ and $12.6 \%$ were not able to be registered and enroll other schools.

According to the information presented in the table above it is mean that $59.8 \%$ of VET students which participated in the assessment were male while $40.2 \%$ female. Even was thought that most of student from the agribusiness VET schools are male it doesn't mean in our case the food technology profile increased rapidly the \% of female participated in the assessment. Most of the VET students in this assessment came from rural areas $52.6 \%$ which mean potential for dealing practically with this field is possible.

Table 5: \% of basic information of VET student which were interviewed

\begin{tabular}{crrr}
\hline & \multicolumn{2}{c}{ Gender } & \multicolumn{2}{c}{ Residential location } \\
\hline $\mathrm{M}$ & $59.8 \%$ & Urban & $47.4 \%$ \\
$\mathrm{~F}$ & $40.2 \%$ & Rural & $52.6 \%$ \\
\hline
\end{tabular}

Looking to the answers of students in the table above majority of them stated that they plan to continue the agriculture faculty $85.3 \%$ which is in opposite of other answerers that they are interest to be increase their capacities and know how to find the jobs.

Table 6: \% of student's opinions about market demand for their qualifications

\begin{tabular}{|c|c|}
\hline \multicolumn{2}{|c|}{ How do you develop your career in agriculture sector } \\
\hline I will be employed in agribusiness as technical & $10.9 \%$ \\
\hline I will become a farmer & $3.8 \%$ \\
\hline I will continue studies at the faculty of agriculture & $85.3 \%$ \\
\hline
\end{tabular}

In the table below we can see that more than half of student $50.2 \%$ stated that they do not have information about labor market demand for their qualifications, $36.1 \%$ they stated yes there is demand and $13.7 \%$ stated no there is no demand for their qualifications.

Table 7: \% of different options of VET students regarding the labor market demand for their qualifications

\begin{tabular}{|c|c|}
\hline Do you think there is demand in the labor market to hire people with qualifications obtained only by agricultural secondary education \\
\hline Yes & $36.10 \%$ \\
\hline No & $13.7 \%$ \\
\hline I don't know & $50.2 \%$ \\
\hline
\end{tabular}


Based on students statements the one of most required profile is the food technology $80.8 \%$, next is the arboriculture 10.8 and horticulture. Which mean that also the number of students is oriented based on their thoughts and opinions in these profiles.
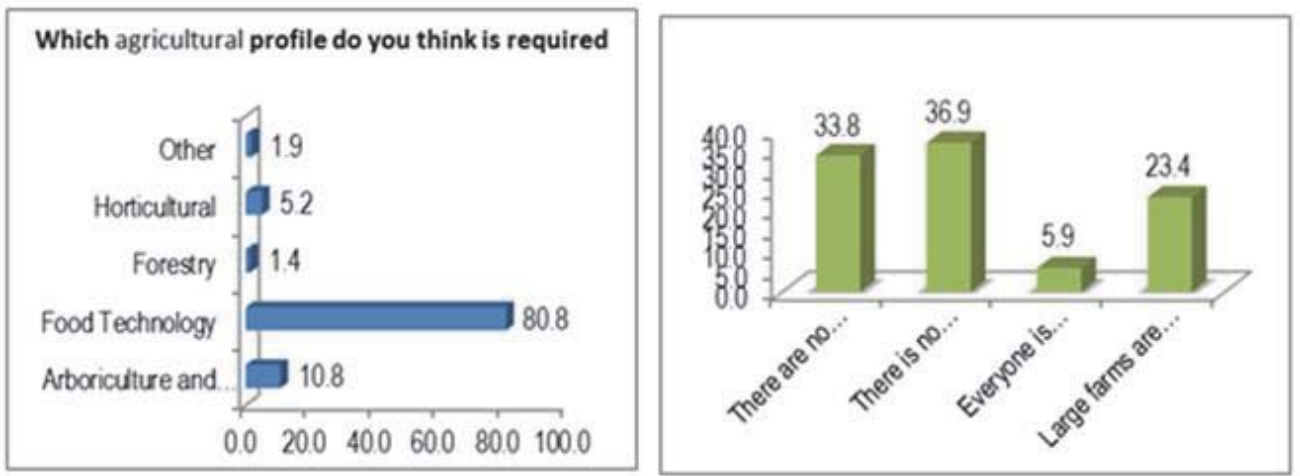

Figure 18: \% of statements of students regarding the VET students Figure 19: \% of opinions of VET students profiles regarding reasons for Demand for employment of

According to the students statement there are few reasons which impacts direct youth employment based on student opinions. One of the most cited is the answer "there is no requirement for employment in the agricultural sector (36.9\%), followed by the answer that "there are no large farms in Kosovo" around $33.8 \%, 23.4 \%$ of students think that large farms are usually family business while small scale $5.9 \%$ is that everyone is involved in Agriculture.

According to the question "Which is most preferred method for job search for young people from VET students" based on students opinion the participation on job fair is the one of most preferred methods around $33.2 \%$ followed by $31.9 \%$ is the announcements of job vacancies through media, printed media, TV and radio, $16.6 \%$ municipal employment office and through the internet $12.2 \%$.KCC come to the conclusion that organizing the planned activities such as Job fair and cooperation with municipal employment office is in the right track but enforcement with cooperation with media will be addressed in future.
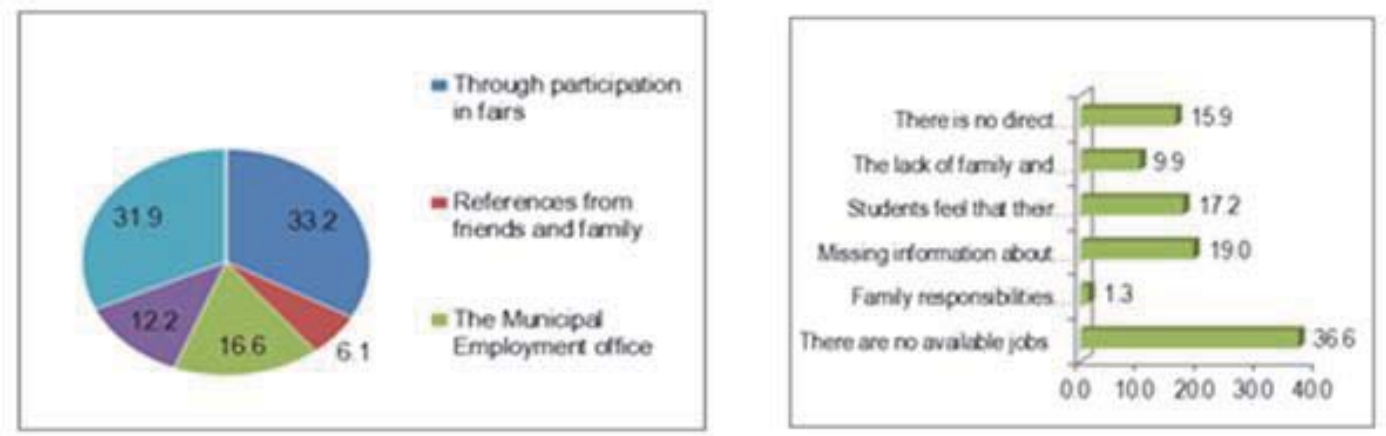

Figure 20: $\%$ of preferred methods for job search youth to base on students option Figure 21: $\%$ of different obstacles that discourage to look for jobs

According to additional question regarding the main obstacles that discourage students to look for job, there are few obstacles according to their statements $36.6 \%$ there are no job available, $19.0 \%$ missing information about available jobs, $15.9 \%$ there are no direct link and information, $9.9 \%$ there is also a nepotism which is one of obstacles. 


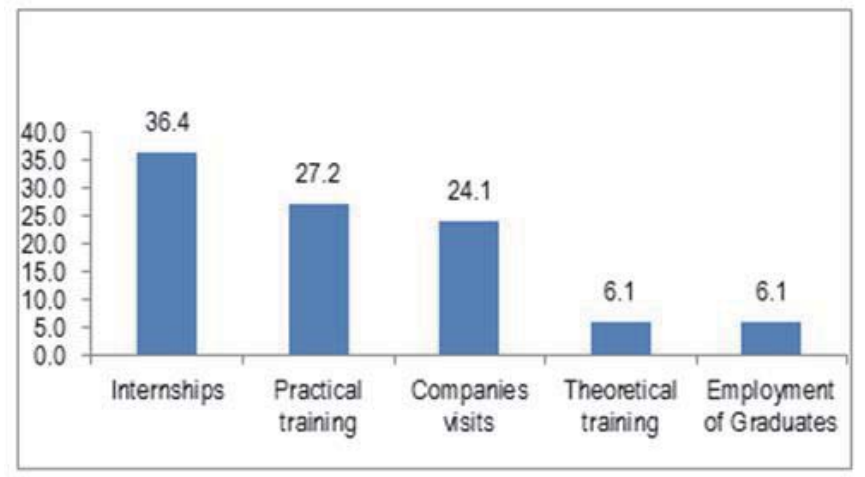

Figure 22: \% of different efforts by schools for VET students to develop relationship with the private sector

According to the question "Are there efforts by schools to develop the relationship with the private sector for the continuation of the practice of Agribusiness school students? If yes, what activities, based on students statements there are the inciatives but almost all the activities are in low scale.Inerniship is one of activity whichis most enforced (36.4\%), practical training by $27.2 \%$ while visits to companies $24.1 \%$ and others are in very low scale.

\section{Discussion}

It is estimated that over $50 \%$ of Kosovo population is under the age of 30 . This fact requires for immediate actions to be taken regarding the education and integration of young generations. A direct consequence of lack of investments in the youth is that a country is wasting young potentials for its development. Youth Strategy in Kosovo adopts an integrated approach for social, economic and political participation of youth in society. In particular, youth need formal and informal education, in line with the needs of labor market, they need youth-friendly health-care services, more security, employment, recreational activities and for participating in decision-making3

Although youth employment remains high on the government's agenda, the policy-making process remains characterized by lack of coherence and coordination between ministries and between central and local government. Hence, the most disadvantaged areas of Kosovo have difficulties in translating the objectives of the youth employment policy into programmes that address the multiple disadvantages faced by young people. The provision of well-targeted active employment measures to young unemployed registered at the Public Employment Service (PES) also depends on the enhanced administrative capacity of public employment services. Furthermore, while creating full employment for Kosovo's young people in the short to medium term will not be possible, a number of measures (requiring external assistance to establish and support, at least initially) could go some way towards easing the unemployment tension. Some of these measures are oriented towards raising the level of qualifications of young people and better matching between VET and labour market needs such as: developing tertiary non-university education (which currently appears as a gaping omission in the country's learning framework) or introducing youth-specific and targeted vocational training provision clearly correlated to existing skills gaps.4

\section{Conclusion}

Findings from assessment of private sector

Based on the results of quantitative analysis it could be easy to come to the following findings that Agribusinesses that were interviewed belong to small, medium and large businesses. The interviewed businesses belong to these subsectors: big food processing (fruit, vegetable, potato, meet, milk etc), livestock farms, traders (wholesalers, retailers and hypermarket chain), farmers with a large growing area that are large producers of fruits, vegetables and sale them as

\footnotetext{
${ }^{3}$ Strategy components - an overview of youth situation in Kosovo
} 
well. These subsectors were selected for interview bearing in mind the fact that they are subsectors with an increased development and promise generation of vacancies. These are subsectors that impact the macroeconomic development of Kosovo. Their geographical position is in the regions near the VET schools, which is one of the reasons that they are selected and that it is very easy to connect VET schools and companies. Therefore, in terms of the agricultural business that were interviewed, despite many difficulties, the data are encouraging, because more than $80 \%$ of them are interested to develop (increase) business, develop new products, increase productivity, and increase the number of employees (especially small and medium businesses)

1. The most average age of the employees around $72.6 \%$ are $25-34$ years old. It is mean that agribusiness companies don't have lot employees from the young generation.

2. In the other side the most of companies around $78.7 \%$ stated that they satisfied with the youth work (fresh graduates)

3. It is interesting that the private sector around $56.8 \%$ preferred young employees to come from public VET schools, 30.7 from public universities, 11.4 from professional certification institutions and very low $\%$ from private universities around 1.1\%.So agribusiness companies are optimistic about students that came from Agribusiness VET schools.

4. In conclusion the agribusiness companies seems to be very interesting in employing the youth from VET schools and interesting profiles are wood technology (100\%), Horticulture profile $(62.0 \%)$, food technology $(57.8 \%)$, plant protection (10.8\%), crop and vegetable production (10.8\%) while the other profile are less required from the agribusiness companies.

5. Required skills from the companies : skills to do "Quality of work, attention to details" (90.8\%), Team working $(84.5 \%$, Knowledge for using equipment (75.6\%), experience in similar positions (61.2\%),Communication Skills (59.8 \%), interpersonal skills(53.7\%) and important skills are Formal education(64.3\%), Foreign language skills (57\%), Training and certification (54.8\%)

6. Almost majority of companies plan to expand businesses, increase productivity and most important think increase number of employees.

\section{Findings from Assessment of VET Students}

The interviews were distributed in the three schools based on number of VET student that schools possess and the profiles that businesses are interest. The $43.5 \%$ of student interviewed were from school "Zenel Hajdini", $36.0 \%$ from VET school "Avdyl Frasheri" and 20.5\% from VET school "Ali Hadri". The different profiles of student were interviewed during the assessment, the one of most frequented was the food processing profile which in this assessment presents $58.3 \%, 12.3 \%$ of veterinary profile, $10.2 \%$ vegetable production profiles, $6.4 \%$ Arboriculture profile. Most of the VET students in this assessment came from rural areas $52.6 \%$ which mean potential for dealing practically with this field is possible.

1. According to the figure above we see that even it was thought that majority of students were enforced from family or they were not able to enroll in other schools, based on the percent presented above most of them liked this field and it was their decision $40.6 \%$, they see that this field is profitable $27.2 \%$, agriculture is their carrier $14.6 \%$ and $12.6 \%$ were not able to be registered and enroll other schools.

2. Half of students $50.2 \%$ stated that they do not have information about labor market demand for their qualifications, $36.1 \%$ they stated yes there is demand and $13.7 \%$ stated no there is no demand for their qualifications. From \% of student which stated that there is demand and one of most required profile is the food technology $80.8 \%$, next is the arboriculture 10.8 and horticulture. Which mean that also the number of students is oriented based on their thoughts and opinions in these profiles.

3. According to the students statement there are few reasons which impacts direct youth employment based on student opinions. One of the most cited is the answer "there is no requirement for employment in the agricultural sector (36.9\%), followed by the answer that "there are no large farms in Kosovo" around $33.8 \%$, $23.4 \%$ of students think that large farms are usually family business while small scale $5.9 \%$ is that everyone is involved in Agriculture.

4. According to the question "Which is most preferred method for job search for young people from VET students" based on students opinion the participation on job fair is the one of most preferred methods around $33.2 \%$ followed by $31.9 \%$ is the announcements of job vacancies through media, printed media, TV and radio, $16.6 \%$ municipal employment office and through the internet $12.2 \%$. 
5. According to additional question regarding the main obstacles that discourage students to look for job, there are few obstacles according to their statements $36.6 \%$ there are no job available, 19.0\% missing information about available jobs, $15.9 \%$ there are no direct link and information, $9.9 \%$ there is also a nepotism which is one of obstacles.

6. According to the question "Are there efforts by schools to develop the relationship with the private sector for the continuation of the practice of Agribusiness school students? If yes, what activities, based on students statements there are the incentives but almost all the activities are in low scale.

7. The most required activity to be supported for increasing capacities are: searching for jobs for graduate, participation in job fair , career guidance for students, visit to the company's and support and ensuring of places for internship in private sector.

\section{Recommendations}

Based on findings from the both assessment and in order to address gaps and needs of Agribusiness sector and VET schools aimed to enhance youth employability and employment the institutions should follow up these recommendations:

1. Work very close with private sector in order to increase awareness regarding the Capacities of VET student from VET schools and organize as much as possible joint activities.

2. Identify agribusiness companies which expressed interest to work and have joint activity with the mentions VET schools;

3. Based on the finding and close cooperation with the education sector prepare the list of students which belong to the required profiles from the companies and work close with them to increase required capacities;

4. Organize the trainings and workshops with identified list of VET students in order to increase their capacities.;

5. The trainings should be focused on these required topics in order to increase skills Training on CV writing, interviewing, and job search skills in each of the three regions, conduct training for the project proposal writing, business plan writing;

6. Strength the relations with other stakeholders engaged in this field without omitted public sector such us: Ministry of labor and social welfare, Ministry of education, sciences and technology and regional employment offices;

7. Organize the regional job fairs;

8. Produce the promotion materials in order to increase the awareness and opportunities of all institutions and private sector companies about unused power and capacities of VET students;

9. Establish tracking system that will monitor on quarterly bases number of students employed (inter, part or full time) after the project is completed

\section{References}

Manqellari Ahmet, Hadëri Sulo, Kule Dhori and Qirici Stefan: "Introduction to Economics", 2002, Tiranë.

Alliance of Kosovar Businesses: Research on Labor Market Needs, 2012

Alliance of Kosovar Businesses: Labor Cost Survey, Prill 2011 Kosovo Youth Strategy and Action Plan 20102012 , page 12.

Hoti Avdulla: Adjustment capacity of labor markets of the Western Balkan countries

Hoti Avdulla: Human Capital and Unemployment in Transition Economies: The Case of Kosovo, 2003

World Bank: Report on economic situation September 2011, Report

Central Bank of Kosovo: Financial Stability Report 2011

Statistics Office of Kosovo: "Labor Market Statistics", July 2010, Prishtinë

Kosovo statistics Agency: Census of population, households and housing in Kosovë

EUROSTAT: Unemployment rate by countries 2011

Ministry of Labor and social Welfare, Work and Employment, annual report 2011

EUROSTAT: Unemployment in EU 27, July 2012

EUROSTAT: Labor Market 2, regional yearbook 2011

Strategy components - an overview of youth situation in Kosovo

HRD country analysis Kosovo, page 7,

Kosovo Agency of Statistics, Results of the Kosovo 2013 labor force survey, JULY 2014

ILO, Global Employment trends, 2011

Ministria e Bujqesise dhe zhvillimit rural:Plani për Bujqësi dhe Zhvillim Rural 2010- 13,2010 Prishtine 


\section{Web pages}

http://www.esiweb.org/pdf/kosovo_ETF\%20Country\%20Analysis\%202008\%20copy.pdf(seen 01.03.2015)

https://www.worldbank.org/content/dam/Worldbank/Brief/Europe\%20and\%20Central\%20Asia/KOS-Labour-Force-Survey-2013Eng.pdf(seen 01.03.2015)

http://www.seerural.org/wp-content/uploads/2009/05/ARDP_2010-13_FINALalb70211.pdf 
